\title{
THE IMPACT OF GOVERNMENT EMERGENCY ORDINANCE NO. 114/2018 ON THE PROFITABILITY OF COMPANIES ACTING IN ENERGY DOMAIN, LISTED ON BUCHAREST STOCK EXCHANGE
}

\author{
Diana Elena VASIU \\ "Lucian Blaga” University, Sibiu, Romania \\ diana.vasiu@ulbsibiu.ro
}

\begin{abstract}
On December 29, 2018, the Government Emergency Ordinance no. 114/2018 has been published. This Ordinance, among others, established a multitude of measures, both economic and fiscal that aimed companies acting in the energy field. The monetary contribution, received from the license holders in the field of energy, was set at the level of $2 \%$, which means an increase of 20 times of this duty. These companies also have the obligation to sell the natural gas quantities, resulting from the current domestic production activity, at the price of 68 lei / MWh to eligible suppliers and final customers. All these measures have had a direct impact on companies acting in the energy field, affecting their profitability and simultaneously their ability to carry out investment projects. This paper analyzes the way the $e$ companies listed on Bucharest Stock Exchange, acting in energy field, were affected by Government Emergency Ordinance no. 114/2018 measures.
\end{abstract}

KEYWORDS: net profit, Bucharest stock exchange, energy, Government Emergency Ordinance no. 114/2018

\section{Introduction}

The Government Emergency Ordinance no. 114 was published on December 29, 2018. Immediately after its public presentation, a strong reaction of the Romanian financial market was noticed. The main companies affected by a strong variation in the stock exchange rate were those acting in the energy and banking field, as a result of the fact that the measures provided by the ordinance would significantly affect their activity.

The normative act established a multitude of measures both economic and fiscal. Among the most important were the imposition of the tax on the assets of the banking system and a tax on the revenues of the online gambling organizers. The fees for granting the radio licenses and the monetary contributions due by the licensees in the field of electricity, electricity and thermal energy in cogeneration for the component of electricity and natural gas have been modified.

The monetary contribution received from the license holders in the field of electricity, electricity and thermal energy in cogeneration and natural gas was set at the level of $2 \%$ of the turnover realized by the economic operators from the activities covered by the licenses granted by the National Energy Regulatory Authority (ANRE). During April $1^{\text {st }} 2019$ and February $28^{\text {th }} 2022$, the producers, who 
carry out both extraction activities and sales activities of the natural gas extracted from the Romanian territory, have the obligation to sell the natural gas quantities, resulting from the current domestic production activity, at the price of 68 lei / MWh to eligible suppliers and final customers.

These limitations and the additional taxation had a negative impact on the profitability of companies acting in energy field, which, during 2019, announcing the reduction of profit, respectively losses, affecting their self financing capacity (Ciuhureanu, 2017) and furthermore, the capacity to develop new investment projects. Also their stock market performance was affected.

Given these legal changes, the purpose of this paper is to highlight how companies listed on Bucharest Stock Exchange have reduced their profitability, or even recorded losses. The energy sector (oil, gas and utilities) currently holds a share of $32 \%$ of the total market capitalization, being on the second place after the financial field. This structure confers a significant influence of the energy sector on the stock market, with a significant impact on the evolution of the BET-NG index.

The company's performance is identified through profitability, namely through its ability to make profit (Petrescu, 2005). The net profit, when it is obtained, can be considered by managers as an important source of self-financing, of investments and influenced the dividend policies (Ciuhureanu, 2017).

\section{Case Study}

\subsection{Methodology}

For the analysis of the evolution of performance, the financial indicators (Petrescu, 2008) for the first, second and third semester of 2019 were compared with the financial indicators registered in the same period of 2014, 2015, 2016, 2017, 2018 and 2019, if data was available. Since not all analyzed companies have published the quarterly financial statements for the $3^{\text {rd }}$ quarter 2019 until the present paper, in some cases was difficult to compare the third 2019 quarter with the same period from 2015-2018.

The data used for the analysis are available on Bucharest Stock Exchange (BSE) website, on tradeville.eu and on each company's website. The companies acting in energy sector, listed on BSE, and those that are part of the BET-NG index composition are approximately the same, as presented in Table no.1. From this, S.N.G.N. ROMGAZ S.A., OMV PETROM S.A., S.N.T.G.N. TRANSGAZ S.A., SOCIETATEA ENERGETICA ELECTRICA S.A., S.N. NUCLEARELECTRICA S.A., C.N.T.E.E. TRANSELECTRICA, ROMPETROL RAFINARE S.A., ROMPETROL WELL SERVICES S.A. have licenses in the field of electricity, electricity and thermal energy in cogeneration for the component of electricity and natural gas, granted by ANRE. Therefore, the evolution of their financial performance will be analyzed.

Table no. 1

Companies acting in energy domain listed on Bucharest stock exchange

\begin{tabular}{|l|l|l|l|}
\hline \multicolumn{2}{|c|}{ Energy field on BSE } & \multicolumn{2}{c|}{ BET-NG index composition } \\
\hline \multicolumn{1}{|c|}{ Symbol } & \multicolumn{1}{c|}{ Name } & Symbol & \multicolumn{1}{c|}{ Name } \\
\hline EL & $\begin{array}{l}\text { SOCIETATEA ENERGETICA } \\
\text { ELECTRICA S.A. }\end{array}$ & SNG & S.N.G.N. ROMGAZ S.A. \\
\hline SNN & S.N. NUCLEARELECTRICA S.A. & SNP & OMV PETROM S.A. \\
\hline TEL & C.N.T.E.E. TRANSELECTRICA & TGN & S.N.T.G.N. TRANSGAZ S.A. \\
\hline
\end{tabular}




\begin{tabular}{|l|l|l|l|}
\hline \multicolumn{2}{|c|}{ Energy field on BSE } & \multicolumn{2}{c|}{ NET-NG index composition } \\
\hline \multicolumn{1}{|c|}{ Symbol } & \multicolumn{1}{|c|}{ Name } & Symbol & \multicolumn{1}{c|}{ Name } \\
\hline TGN & S.N.T.G.N. TRANSGAZ S.A. & EL & $\begin{array}{l}\text { SOCIETATEA ENERGETICA } \\
\text { ELECTRICA S.A. }\end{array}$ \\
\hline COTE & CONPET & SNN & S.N. NUCLEARELECTRICA S.A. \\
\hline SNG & S.N.G.N. ROMGAZ S.A & TEL & C.N.T.E.E. TRANSELECTRICA \\
\hline SNP & OMV PETROM S.A. & COTE & CONPET SA \\
\hline RRC & $\begin{array}{l}\text { ROMPETROL WELL SERVICES } \\
\text { S.A. }\end{array}$ & RRC & ROMPETROL RAFINARE S.A. \\
\hline PTR & $\begin{array}{l}\text { ROMPETROL WELL SERVICES } \\
\text { S.A. }\end{array}$ & OIL & OIL TERMINAL S.A. \\
\hline OIL & OIL TERMINAL S.A. & PTR & $\begin{array}{l}\text { ROMPETROL WELL SERVICES } \\
\text { S.A. }\end{array}$ \\
\hline DAFR & DAFORA & & \\
\hline
\end{tabular}

\subsection{Data Analysis}

Since the monetary contribution received from the license holders in the field of energy was set at the level of $2 \%$ of the turnover, in the beginning, the evolution of the turnover was analyzed. For each company, the evolution of the turnover was analyzed, by comparison with the previous period, through the calculation of the individual index (Balteș, 2010), according to the following formula:

$$
\mathrm{I}_{\text {TURNOVER 1/0 }}=\frac{\text { Turnover }_{1}}{\text { Turnover }_{0}}
$$

Also, at each company level, an average turnover index was calculated, for the entire period, as the average of the indices using the individual indices presented above. The data are presented in Table no. 2.

Table no. 2

The individual and average index of turnover

\begin{tabular}{|l|c|c|c|c|c|}
\hline \multicolumn{2}{|c}{ The individual and average index of turnover for the $\mathbf{1}^{\text {st }}$ quarter } \\
\hline & \multicolumn{4}{c|}{ Individual index of turnover } & \multirow{2}{*}{$\begin{array}{c}\text { The average } \\
\text { indices }\end{array}$} \\
\cline { 2 - 5 } & $\boldsymbol{I}_{\mathbf{2 0 1 6 / 2 0 1 5}}$ & $\boldsymbol{I}_{2017 / 2016}$ & $\boldsymbol{I}_{\mathbf{2 0 1 8 / 2 0 1 7}}$ & $\boldsymbol{I}_{2019 / 2018}$ & 1,06 \\
\hline S.N.G.N. ROMGAZ S.A & 1,03 & 1,06 & 0,99 & 1,16 & 1,06 \\
\hline OMV PETROM S.A., & 0,83 & 4,68 & 0,29 & 1,11 & 1,01 \\
\hline $\begin{array}{l}\text { ROMPETROL WELL } \\
\text { SERVICES S.A. }\end{array}$ & 0,46 & 0,92 & 1,89 & 1,29 & 1,04 \\
\hline $\begin{array}{l}\text { SOCIETATEA ENERGETICA } \\
\text { ELECTRICA S.A }\end{array}$ & 1,04 & 0,99 & 0,97 & 1,17 & 1,11 \\
\hline $\begin{array}{l}\text { S.N. NUCLEARELECTRICA } \\
\text { S.A., }\end{array}$ & 1,04 & 1,05 & 1,13 & 1,23 & 0,95 \\
\hline C.N.T.E.E. TRANSELECTRICA & 0,95 & 1,52 & 0,60 & 0,95 & 1,01 \\
\hline S.N.T.G.N. TRANSGAZ S.A & 1,05 & 1,36 & 0,81 & 0,90 & 1,09 \\
\hline ROMPETROL RAFINARE S.A., & 0,75 & 1,21 & 1,41 & 1,09 & \\
\hline
\end{tabular}




\begin{tabular}{|l|c|c|c|c|c|}
\hline \multicolumn{7}{|c}{ The individual and average index of turnover for the $\mathbf{2}^{\text {nd }}$ quarter } \\
\hline \multirow{2}{*}{ Company } & \multicolumn{3}{c|}{ Individual index of turnover } & \multirow{2}{*}{$\begin{array}{c}\text { The average } \\
\text { indices }\end{array}$} \\
\cline { 2 - 5 } & $\boldsymbol{I}_{2016 / 2015}$ & $\boldsymbol{I}_{\mathbf{2 0 1 7 / 2 0 1 6}}$ & $\boldsymbol{I}_{2018 / 2017}$ & $\boldsymbol{I}_{2019 / 2018}$ & 1,06 \\
\hline S.N.G.N. ROMGAZ S.A & 0,83 & 1,29 & 1,03 & 1,16 & 1,14 \\
\hline OMV PETROM S.A. & 0,82 & 1,30 & 1,11 & 1,42 & 1,03 \\
\hline $\begin{array}{l}\text { ROMPETROL WELL } \\
\text { SERVICES S.A. }\end{array}$ & 0,46 & 1,14 & 1,84 & 1,16 & 1,03 \\
\hline $\begin{array}{l}\text { SOCIETATEA ENERGETICA } \\
\text { ELECTRICA S.A. }\end{array}$ & 0,99 & 2,00 & 0,02 & 1,62 & 0,50 \\
\hline $\begin{array}{l}\text { S.N. NUCLEARELECTRICA } \\
\text { S.A. }\end{array}$ & 0,88 & 1,18 & 1,11 & 1,22 & 1,09 \\
\hline $\begin{array}{l}\text { C.N.T.E.E. TRANSELECTRICA } \\
\text { S.N.T.G.N. TRANSGAZ S.A. }\end{array}$ & 0,95 & 1,29 & 0,71 & 0,96 & 0,95 \\
\hline ROMPETROL RAFINARE S.A. & 0,75 & 1,14 & 1,49 & 1,12 & 1,09 \\
\hline
\end{tabular}

Comparing the evidences for the $1^{\text {th }}$ quarter, as presented in Figure no. 1, an increase from $35 \%$ to $75 \%$ was found in the share of companies that registered an increase of turnover, in 2019/2018 compared to $2018 / 2017$.

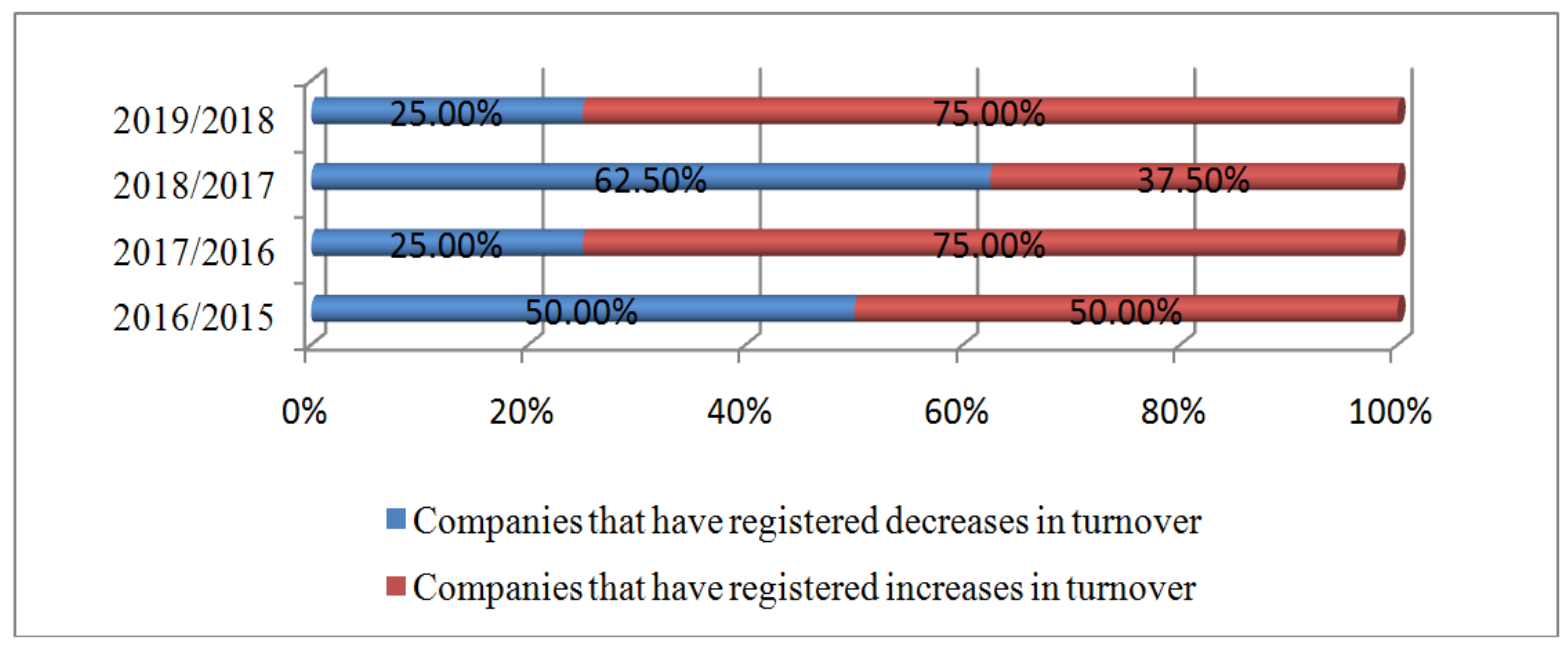

Figure no. 1: The Situation of the companies that registered increases / decreases of the turnover. Comparative situation for $1^{\text {st }}$ quarter

For the entire period 2015-2019, $1^{\text {st }}$ quarter, as presented in Figure no. 2, the highest Turnover Average Index was recorded in case of S.N. NUCLEARELECTRICA S.A., which corresponds to a constant increase in turnover, being the only company that registered only increases in turnover, while the rest of the companies also recorded decreases. 


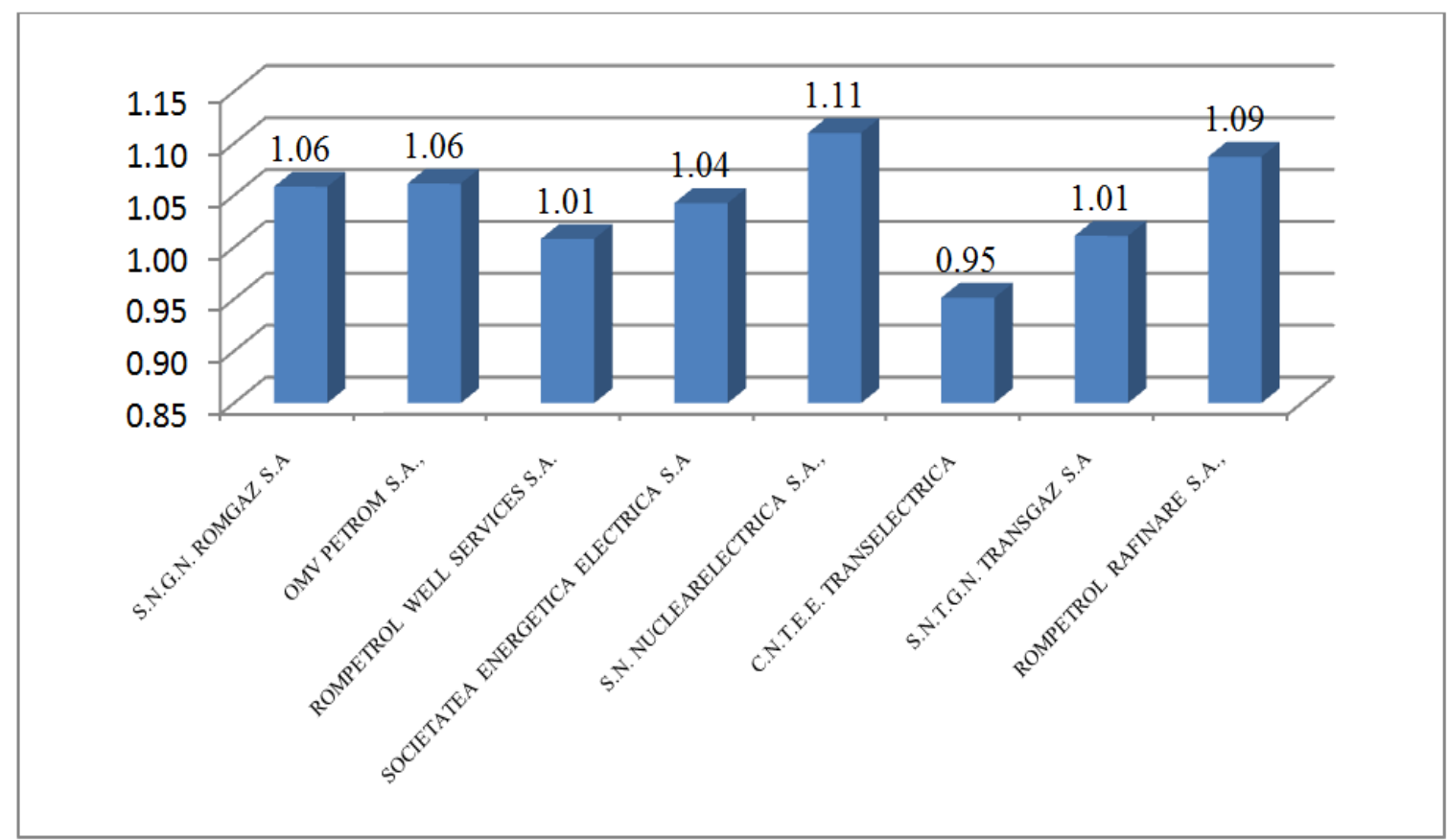

Figure no. 2: The average indices of turnover. Comparative situation for $2^{\text {nd }}$ quarter

For the $2^{\text {nd }}$ quarter, the same evidence of increased turnover can be noted, as presented in Figure no. 3, from $62,5 \%$ to $75 \%$. This time, the difference between the companies that registered increases of the turnover between 2019/2018 compared to $2018 / 2017$ is not so great, as in case of the $1^{\text {st }}$ quarter.

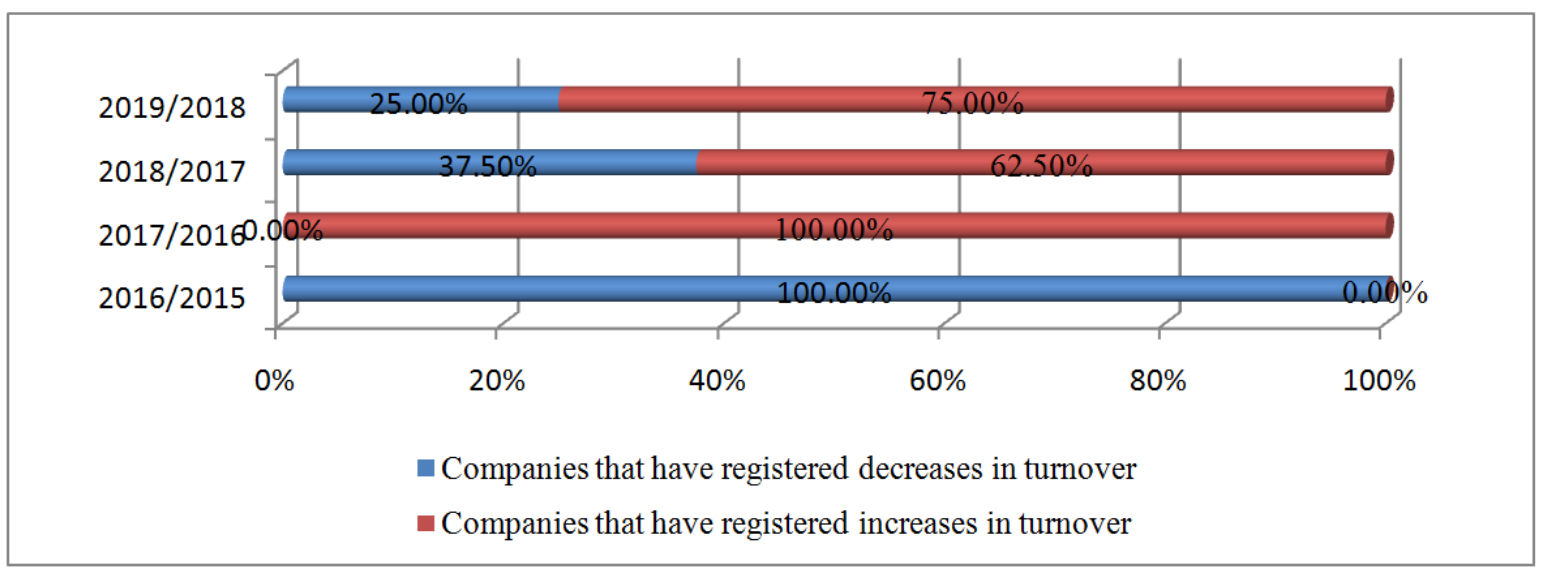

Figure no. 3: The situation of the companies that registered increases/ decreases of the turnover. Comparative situation for $2^{\text {nd }}$ quarter

During entire period 2015-2019, $2^{\text {nd }}$ quarter, as presented in Figure no. 4, the highest Turnover Average Index was recorded in case of OMV PETROM S.A.
In the second quarter, no company achieved only increases in turnover from one year to another. Decreases in certain years were offset by increases in other periods. 


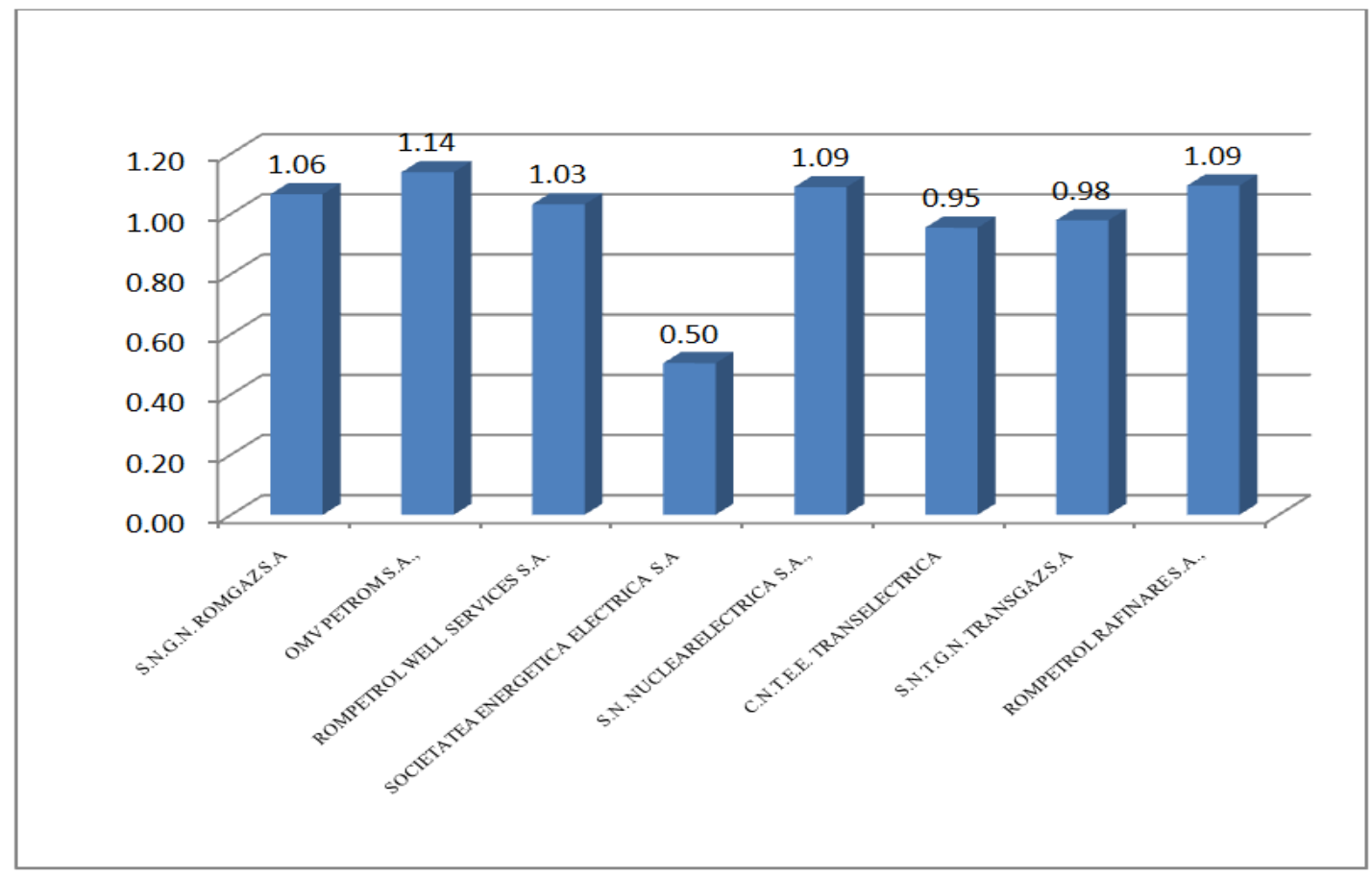

Figure no. 4: The average indices of turnover. Comparative situation for $2^{\text {nd }}$ quarter

Given these evolutions of turnover, an increase is expected in the monetary contributions due the licensees in the field of electricity. The impact is expected to be even greater, as this tax has increased 20 times, from $0.2 \%$ to $2 \%$. To this was added the cap on the sale price of gas for the population. As a result, a reduction in the profit obtained by the energy companies in 2019 is expected, both compared to the similar period of last year and from one period to another, for the last five decades. Further, the evolution of the net profit, presented in Table no. 3 will be analyzed.

Table no. 3

The net profit for the last five decades

\begin{tabular}{|l|r|r|r|r|r|}
\hline \multicolumn{1}{|c|}{ Company } & \multicolumn{1}{c|}{$\mathbf{2 0 1 8 Q 3}$} & \multicolumn{1}{c|}{$\mathbf{2 0 1 8}$} & $\mathbf{2 0 1 9 Q 1}$ & \multicolumn{1}{c|}{$\mathbf{2 0 1 9} \mathbf{Q 2}$} & \multicolumn{1}{c|}{$\mathbf{2 0 1 9} \mathbf{Q 3}$} \\
\hline S.N.G.N. ROMGAZ S.A & 1.160 .123 .000 & 1.428 .383 .000 & 541.845 .000 & 975.909 .000 & 1.185 .104 .000 \\
\hline OMV PETROM S.A. & 2.667 .150 .000 & 4.078 .100 .000 & 1.151 .180 .000 & 1.974 .540 .000 & 2.759 .850 .000 \\
\hline $\begin{array}{l}\text { ROMPETROL WELL } \\
\text { SERVICES S.A. }\end{array}$ & 7.552 .580 & 17.956 .755 & 3.560 .396 & 6.848 .548 & 9.832 .499 \\
\hline $\begin{array}{l}\text { SOCIETATEA } \\
\text { ENERGETICA } \\
\text { ELECTRICA S.A }\end{array}$ & 314.910 .000 & 230.395 .000 & -40.855 .000 & 108.786 .000 & 160.896 .000 \\
\hline $\begin{array}{l}\text { S.N. } \\
\text { NUCLEARELECTRICA } \\
\text { S.A. }\end{array}$ & 9.175 .870 .871 & 8.801 .132 .485 & 9.017 .532 .509 & 8.650 .536 .882 & 8.737 .114 .795 \\
\hline $\begin{array}{l}\text { C.N.T.E.E. } \\
\text { TRANSELECTRICA }\end{array}$ & 97.528 .518 & 75.380 .000 & 37.994 .539 & 19.162 .000 & 73.596 .399 \\
\hline $\begin{array}{l}\text { S.N.T.G.N. } \\
\text { TRANSGAZ S.A }\end{array}$ & $5,160,777,206$ & 299.281 .945 & 495.675 .108 & 191.387 .503 & 195.500 .934 \\
\hline $\begin{array}{l}\text { ROMPETROL } \\
\text { RAFINARE S.A. }\end{array}$ & -61.687 .888 & 30.428 .112 & -230.205 .630 & -59.600 .700 & -80.837 .279 \\
\hline
\end{tabular}


Analyzing the evolution of net profit, for the last 5 decades $\left(3^{\text {rd }}\right.$ quarter $2019 ; 2^{\text {nd }}$ quarter $2019 ; 1^{\text {st }}$ quarter $2019 ; 2018 ; 3^{\text {rd }}$ quarter 2018), presented in Table no. 3 , it is noted that all companies, excepting ROMPETROL RAFINARE S.A. and SOCIETATEA ENERGETICA ELECTRICA $S . A$ have reordered profit.

The financial difficulties of the energy companies, respectively the reduction of profitability are less evident in the $1^{\text {st }}$ and $2^{\text {nd }}$ quarter.
Comparing to the similar period of last year for the $1^{\text {st }}$ quarter, as presented in Table no. 4 , the decreases in net profit were recorded by C.N.T.E.E. TRANSELECTRICA and S.N.T.G.N. TRANSGAZ S.A while ROMPETROL RAFINARE S.A and SOCIETATEA ENERGETICA ELECTRICA S.A increased their loss, compared to the previous period 2018, during $1^{\text {st }}$ quarter, shifting from profit to loss.

Table no. 4

The net profit in the $1^{\text {st }}$ quarter

\begin{tabular}{|l|c|c|c|c|}
\hline \multicolumn{1}{|c|}{ Company } & $\mathbf{2 0 1 8 Q 1}$ & $\mathbf{2 0 1 9}$ Q1 & $\begin{array}{c}\text { Difference } \\
\mathbf{2 0 1 9} \text { Q1- } \\
\mathbf{2 0 1 8} \mathbf{Q 1}\end{array}$ & $\begin{array}{c}\text { Evolution of the net } \\
\text { profit } \\
\mathbf{2 0 1 9} \text { Q1 compared } \\
\text { with 2018 Q1 }\end{array}$ \\
\hline $\begin{array}{l}\text { S.N.G.N. ROMGAZ } \\
\text { S.A. }\end{array}$ & 501196000 & 541845000 & 40649000 & Increase of $8,11 \%$ \\
\hline OMV PETROM S.A. & 854080000 & 1151180000 & 297100000 & Increase of $34,79 \%$ \\
\hline $\begin{array}{l}\text { ROMPETROL WELL } \\
\text { SERVICES S.A. }\end{array}$ & 1287358 & 3560396 & 2273038 & Increase of $176,57 \%$ \\
\hline $\begin{array}{l}\text { SOCIETATEA } \\
\text { ENERGETICA } \\
\text { ELECTRICA S.A. }\end{array}$ & 59256000 & -40855000 & -100111000 & Shift from profit to loss \\
\hline $\begin{array}{l}\text { S.N. } \\
\text { NUCLEARELECTRICA } \\
\text { S.A. }\end{array}$ & 189997143 & 219285421 & 29288278 & Increase of $15,42 \%$ \\
\hline $\begin{array}{l}\text { C.N.T.E.E. } \\
\text { TRANSELECTRICA }\end{array}$ & 68196292 & 37994539 & -30201753 & Decrease of $44,29 \%$ \\
\hline $\begin{array}{l}\text { S.N.T.G.N. TRANSGAZ } \\
\text { S.A. }\end{array}$ & 236604789 & 191387503 & -45217286 & Decrease of $19,11 \%$ \\
\hline $\begin{array}{l}\text { ROMPETROL } \\
\text { RAFINARE S.A. }\end{array}$ & 50481057 & -59600700 & -110081757 & Shift from profit to loss \\
\hline
\end{tabular}

Comparing the similar period of last year for the $2^{\text {nd }}$ quarter, as presented in Table no. 5, the largest decreases in net profit were recorded by C.N.T.E.E. TRANSELECTRICA $\quad(78,51 \%) \quad$ and SOCIETATEA ENERGETICA ELECTRICA
S.A. $(63,92 \%)$ while ROMPETROL RAFINARE S.A. faced the same situation as previous comparison quarter $1^{\text {st }}$, increasing its loss, this being 31,4\% greater. 
Table no. 5

The net profit in the $2^{\text {nd }}$ quarter

\begin{tabular}{|l|c|c|c|c|}
\hline \multicolumn{1}{|c|}{ Company } & $\mathbf{2 0 1 8}$ Q2 & $\mathbf{2 0 1 9}$ Q2 & $\begin{array}{c}\text { Difference } \\
\mathbf{2 0 1 9} \text { Q2- } \\
\mathbf{2 0 1 8} \text { Q2 }\end{array}$ & $\begin{array}{c}\text { Evolution } \\
\text { of the net profit } \\
\mathbf{2 0 1 9} \text { Q3 compared } \\
\text { with 2018 Q2 }\end{array}$ \\
\hline S.N.G.N. ROMGAZ S.A. & 815080320 & 975909000 & 24981000 & Increase of $19,73 \%$ \\
\hline OMV PETROM S.A. & 1441912832 & 1974540000 & 92700000 & Increase of $36,94 \%$ \\
\hline $\begin{array}{l}\text { ROMPETROL WELL } \\
\text { SERVICES S.A. }\end{array}$ & 4035658 & 6848548 & 2279919 & Increase of $69,70 \%$ \\
\hline $\begin{array}{l}\text { SOCIETATEA ENERGETICA } \\
\text { ELECTRICA S.A. }\end{array}$ & 301497120 & 108.786 .000 & -154014000 & Decrease of $63,92 \%$ \\
\hline S.N. NUCLEARELECTRICA S.A. & 182314400 & 290619141 & -438756076 & Increase of $59,41 \%$ \\
\hline $\begin{array}{l}\text { C.N.T.E.E. } \\
\text { TRANSELECTRICA }\end{array}$ & 89155000 & 19162000 & -23932119 & Decrease of $78,51 \%$ \\
\hline S.N.T.G.N. TRANSGAZ S.A. & 279606304 & 195500934 & -4965276272 & Decrease of $30,08 \%$ \\
\hline $\begin{array}{l}\text { ROMPETROL RAFINARE } \\
\text { S.A. }\end{array}$ & -61687888 & -80837279 & -19149391 & $\begin{array}{c}\text { Increase } 1005 \\
\text { of } 31,04 \%\end{array}$ \\
\hline
\end{tabular}

The reduction of profitability becomes more obvious while comparing the similar period of last year for the $3^{\text {rd }}$ quarter, as presented in Table no 6. The largest decreases in net profit were recorded by S.N.T.G.N. TRANSGAZ S.A. (96,21\%), SOCIETATEA ENERGETICA ELECTRICA S.A. $(48,91 \%)$ and C.N.T.E.E. TRANSELECTRICA (24,54\%). The situation of ROMPETROL RAFINARE S.A. is the same, increasing its loss while shifting from profit to loss.

Excepting ROMPETROL WELL SERVICES S.A, which registered an increase in net profit of $30,19 \%$, the other two companies, S.N.G.N. ROMGAZ S.A. and OMV PETROM S.A., with an increase lower that $3,5 \%$, are not very comfortable in profitability.

Table no. 6 The net profit in the $3^{\text {rd }}$ quarter

\begin{tabular}{|c|c|c|c|c|}
\hline Company & 2018 Q3 & 2019 Q3 & $\begin{array}{l}\text { Difference } \\
2019 \text { Q3- } \\
2018 \text { Q3 }\end{array}$ & $\begin{array}{c}\text { Evolution } \\
\text { of the net profit } \\
2019 \text { Q3 compared } \\
\text { with } 2018 \text { Q3 } \\
\end{array}$ \\
\hline S.N.G.N. ROMGAZ S.A. & 1160123000 & 1185104000 & 24981000 & Increase of $2,15 \%$ \\
\hline OMV PETROM S.A. & 2667150000 & 2759850000 & 92700000 & Increase of $3,48 \%$ \\
\hline $\begin{array}{l}\text { ROMPETROL WELL } \\
\text { SERVICES S.A. }\end{array}$ & 7552580 & 9832499 & 2279919 & Increase of $30,19 \%$ \\
\hline $\begin{array}{l}\text { SOCIETATEA ENERGETICA } \\
\text { ELECTRICA S.A. }\end{array}$ & 314910000 & 160896000 & -154014000 & Decrease of $48,91 \%$ \\
\hline S.N. NUCLEARELECTRICA S.A. & 9175870871 & 8737114795 & -438756076 & Decrease of $4,78 \%$ \\
\hline $\begin{array}{l}\text { C.N.T.E.E. } \\
\text { TRANSELECTRICA }\end{array}$ & 97528518 & 73596399 & -23932119 & Decrease of $24,54 \%$ \\
\hline S.N.T.G.N. TRANSGAZ S.A. & 5160777206 & 195500934 & -4965276272 & Decrease of $96,21 \%$ \\
\hline $\begin{array}{l}\text { ROMPETROL RAFINARE } \\
\text { S.A. }\end{array}$ & 30428112 & -319592063 & -350020175 & $\begin{array}{l}\text { Shift from profit to } \\
\text { loss }\end{array}$ \\
\hline
\end{tabular}




\section{Conclusions}

If, while comparing the $1^{\text {st }}$ Quarter 2019 with the $1^{\text {st }}$ Quarter 2018, the decrease in profitability of the energy companies is not so obvious, the situation becomes evident at the level of the $3^{\text {rd }}$ quarter. Four companies out of eight $(50 \%$ of them) registered a decrease of net profit, two other have shifted from profit to losses. In case of net profit increases, this is less than $5 \%$, excepting the case of only one company, namely ROMPETROL WELL SERVICES S.A. Therefore, it can be stated that the measures imposed by Ordinance 114 had a significant impact on profitability of companies listed on Bucharest Stock Exchange, acting in energy field. Reducing profitability or accumulating losses will affect their future performance in terms of investment policy and dividend policy. Further, these will affect the stock quotes of these companies and the BET-NG index evolution respectively will reduce the return of investors acting in this field.

However, prudence must be maintained in drawing conclusions, the data analyzed being available only for three quarters, and furthermore, some of them being unaudited. Future research are needed to a more accurately determination of the impact of these legal regulations and to exclude other causes that could have generated such losses.

\section{REFERENCES}

Balteş, N. (2010). Analiză şi diagnostic financiar. Sibiu: Editura Universității "Lucian Blaga".

Bucharest Stock Exchange (BSE). (2019). available at: www.bvb.ro, accessed on 01 November 2019.

Ciuhureanu, A. T. (2017). Accounting information integration in the triangle financing investment - dividend. options within economic entities in Central Region. Revista Economica, Vol. 69, Issue 4, 68-83.

Ciuhureanu, A. T. (2017). Instruments and Fianancial Performance Indicators or The Capitalization of Accounting Information from The Profit and Loss Account - Meanings Useful to Management. International Conference Knowledge-Based Organization, Vol. XXIII, Issue 2, 36-40.

Petrescu, S. (2005). Performanţă şi risc în analiza financiară. Analele Ştiinţifice ale Universităţii "Alexandru Ioan Cuza”, Vol. 50-51, Iaşi.

Petrescu, S. (2008). Analiză şi diagnostic financiar-contabil: ghid teoretico-aplicativ. Bucureşti: Editura CECCAR.

Romanian Energy Regulatory Authority (ANRE). (2019). available at: www.anre.ro, accessed on 01 November 2019.

Romanian Government. (2018). The Government Emergency Ordinance no. 114 (OUG 114). Bucharest: Official Gazette, no. 1116.

Tradeville S.A. (2019). available at: https://virtual.tradeville.eu/, accessed on 05 September 2019. 